\title{
PRIMARY ENTROPION IN PERSIAN CATS
}

\author{
ENTRÓPIO PRIMÁRIO EM GATOS PERSAS
}

\author{
José Luiz Laus ${ }^{1}$ Felipe Antônio Mendes Vicenti ${ }^{2}$ Ivia Carmen Talieri ${ }^{2}$ \\ Adriana Torrecilhas Jorge ${ }^{2}$ Aline Adriana Bolzan ${ }^{2}$
}

\section{- CASES REPORT -}

\section{RESUMO}

Entropion is defined as the inward rolling of the eyelid margin in which the eyelashes and eyelid hair (frequently the lower lateral lid) rub the cornea. Etiologies may be congenital, spastic, or cicatricial. This condition usually causes epiphora, blepharospasm, photophobia, conjunctivitis, purulent discharge, corneal vascularization, pigmentation and ulceration, if not surgically treated. Congenital entropion commonly affects dogs and is frequently hereditary in some breeds, whereas cats are uncommonly affected. A predilection for the Persian breed to present primary entropion has been suggested. The authors report two cases of entropion in Persian cats referred to the Ophthalmology Section of Veterinary College of São Paulo State University - UNESP, Jaboticabal - SP / Brazil. First case: a male Persian cat, 2 years old, with a history of bilateral ocular irritation and purulent discharge for 8 months. Ophthalmic examination revealed epiphora, blepharospasm, photophobia, bilateral entropion affecting the whole length of the lower eyelids, conjunctivitis and purulent discharge. Second case: a male Persian cat, 1 year old, with a history of bilateral ocular irritation and purulent discharge for 3 weeks. At ophthalmic examination the animal was presenting epiphora, blepharospasm, photophobia, bilateral entropion affecting the whole length of the lower lids, conjunctivitis, purulent discharge, corneal vascularization, superficial ulceration and edema. The entropion persisted after topical anaestesia in both cats. Surgical treatment was similar in both cases, based on the modified Holtz-Celsus procedure. Grid keratotomy procedure was also performed in the second case. Both cats had a satisfactory clinic evolution which was confirmed few days after surgery.

Key words: eyelids, entropion, cats

\section{RESUMO}

O entrópio é caracterizado por uma inversão da margem palpebral, na qual os cílios e os pêlos da pálpebra (freqüentemente a porção lateral da pálpebra inferior) atritam a córnea. A etiologia desta condição pode ser congênita, espástica ou cicatricial. Esta doença usualmente causa epifora, blefarospasmo, fotofobia, conjuntivite, secreção purulenta, vascularização, pigmentação e ulceração corneanas, se não for tratada cirurgicamente. $O$ entrópio congênito comumente afeta cães e freqüentemente é hereditário em algumas raças, enquanto que os gatos raramente são acometidos. Uma predisposição da raça Persa tem sido sugerida. Os autores relatam dois casos de entrópio felino encaminhados ao Setor de Oftalmologia da Faculdade de Ciências e Veterinárias da Universidade Estadual Paulista UNESP, Jaboticabal - SP / Brasil. Primeiro caso: felino macho, da raça Persa, com dois anos de idade e histórico de irritação ocular bilateral e secreção purulenta durante 8 meses. Ao exame oftálmico, observou-se epifora, blefarospasmo, fotofobia, entrópio bilateral, o qual afetava toda a extensão das pálpebras inferiores, conjuntivite e secreção purulenta. Segundo caso: felino macho, da raça Persa, com 1 ano de idade e histórico de irritação ocular bilateral e secreção purulenta durante 3 semanas. Ao exame oftálmico, o animal apresentava epífora, blefarospasmo, fotofobia, entrópio bilateral, o qual afetava toda a extensão das pálpebras inferiores, conjuntivite, secreção purulenta, vascularização corneana, ulceração superficial e edema. O procedimento cirúrgico empregado foi similar em ambos os casos baseando-se na técnica de Holtz-Celsus modificada. A ceratotomia em grade foi realizada no segundo caso. Os gatos obtiveram uma evolução clínica satisfatória, confirmada poucos dias após a cirurgia.

Palavras-chave: pálpebras, entrópio, gatos.

\section{INTRODUCTION}

Entropion is a common eyelid disorder in dogs, however cats are unusually affected. It consists of a turning of the eyelid margin in which the eyelashes and eyelid hair irritate the cornea causing

\footnotetext{
${ }^{1}$ Associate Professor, DVM, PhD., Ophthalmology Section, Veterinary College, São Paulo State University, Rodovia Carlos Tonanni, Km 5, 14870-000, Jaboticabal, SP - Brazil. E-mail: jllaus@fcav.unesp.br. Autor para correspondência.

${ }^{2}$ Graduate Students, Ophthalmology Section, Veterinary College, São Paulo State University.
} Recebido para publicação em 07.07.98. Aprovado em 27.01.99 
epiphora, blepharospasm, photophobia, conjunctivitis and purulent discharge, corneal vascularization, pigmentation and ulceration if not surgically treated (HELPER, 1989; SLATTER, 1990b; GELATT, 1991b; PETERSEN-JONES, 1993).

The etiologies of this condition may be congenital, spastic, acquired, or cicatricial (HELPER, 1989; SLATTER, 1990b; GELATT, 1991b). Pathophysiology includes tarsus to globe relationship, and the tone of the orbicularis oculi muscle. Loose and overlong eyelids, associated with less than optimal globe position, interfere with the relationship between the eyelids and the globe (GELATT, 1991b; PETERSEN-JONES, 1993). Congenital entropion commonly affects dogs and it is frequently an inherited disease in some breeds, such as Chow-chow, Shar-pei, English and American Cocker Spaniel, English Bulldog, Toy and Miniature Poodles, St. Bernard, Great Danes and Bull Mastiff (SLATTER, 1990b; GELATT, 1991b). The lateral part of both lower eyelids are usually affected (SLATTER, 1990b).

Spastic entropion in dogs usually occurs due to ocular pain and blepharospasm. The increased tone and spasm of the orbicularis oculi muscle increases eyelid margin inversion (SLATTER, 1990b; GELATT, 1991b). Cicatricial entropion may be caused by fibrosis related to surgery, trauma and chronic inflammatory processes (GELATT, 1991b).

Although cicatricial entropion does occur, feline entropion is frequently secondary to painful ocular diseases that cause chronic blepharospasm (SLATTER, 1990b; NASISSE, 1991). Due to the tendency of the eyelid inversion to became permanent, this type of entropion might be described as spastic-cicatricial (NASISSE, 1991) In spite of the low prevalence of eyelids diseases in cats, primary entropion does occur with a predilection for the Persian breed (SLATTER, 1990b; NASISSE, 1991). The surgical correction based on the modified Holtz-Celsus technique is the procedure of choice for treating feline entropion (NASISSE, 1991; PETERSEN-JONES, 1993).

The low prevalence of feline entropion, the importance on the pathophysiological evolution in primary entropion and success of surgical treatment in these two cases motivated the authors to report them. The purporse of this report is to emphasize the predilection for the Persian breed to present primary entropion and also to relate its clinical presentation.

\section{CASES REPORT}

Two cases of entropion in cats were referred to the Ophthalmology Section of Veterinary
College of São Paulo State University - UNESP, Jaboticabal - SP / Brazil. First case: a male Persian cat, two years old, with a history of bilateral ocular irritation and purulent discharge for 8 months. The ophthalmic examination showed epiphora, blepharospasm, photophobia, severe bilateral entropion affecting the whole length of the lower eyelids, conjunctivitis and purulent discharge (figure 1). A great amount of skin on the outer surface of the inrolled eyelids was rubbing the globe. The eyelid surface was white from constant contact with tears. Blepharospasm was intense and the animal kept its eyelids closed. After topical anaesthesia the eyelid defect persisted. Following the preliminary procedures for surgery, the animal was taken into the surgical center and submitted to inhalatory anaesthesia by employing halothane ${ }^{\mathrm{a}}$ in a closed circuit. The predetermined amount of skin and a strip of the orbicularis oculi muscle were excised using sharp, straight scissors. Interrupted sutures with 4-0 Vicryl $\AA^{\mathrm{b}}$ were carefully placed througth the skin, perpendicular to the wound margins and 1 to 2 $\mathrm{mm}$ from the eyelid margin.

Second case: a male Persian cat, one year old, with the history of bilateral ocular irritation and purulent discharge for 3 weeks. At the ophthalmic examination the animal presented epiphora, blepharospasm, photophobia, severe bilateral entropion affecting the whole length of the lower eyelids, conjunctivitis, purulent discharge, corneal vascularization, superficial ulceration, and edema (figure 2). Clinical signs were more evident due to ocular pain caused by corneal ulceration. After topical anaesthesia the eyelid defect also persisted. Modified Holtz-Celsus and grid keratotomy

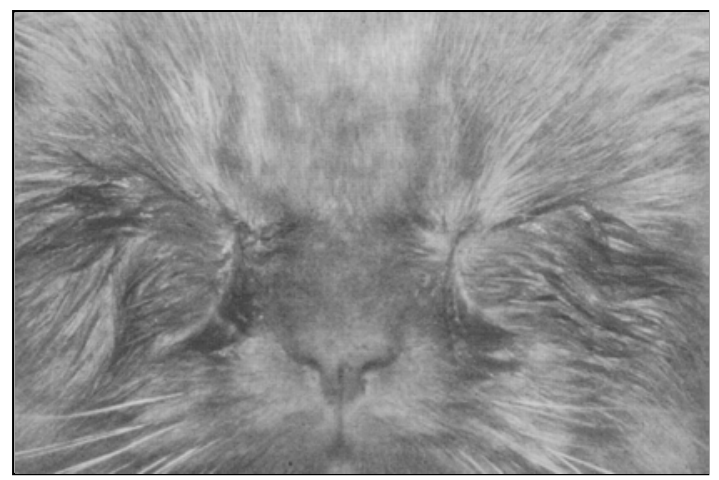

Figure 1 - First case: epiphora, blepharospasm, severe bilateral entropion affecting the whole length of the lower eyelids and purulent discharge in a male persian cat, two years old presented to the ophtalmology section of $\mathrm{Ce}$ terinary College of São Paulo State University UNESP - Jaboticabal - SP/Brazil. 


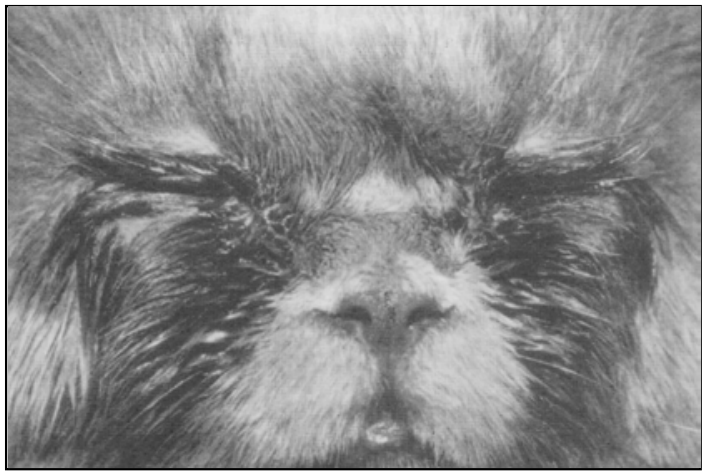

Figure 2 - Second case: epiphora, blepharospasm, severe bilateral entropion affecting the whole length of the lower eyelids and purulent discharge in a male Persian cat, one year old presented to the ophtalmology section of Ceterinary College of São Paulo State University - UNESP Jaboticabal - SP/Brazil

procedures were performed. The length and width of the lower eyelid skin-muscle resection were similar to the first case.

Postoperative treatment consisted of topical application of 0,5 to $1 \mathrm{~cm}$ of ophthalmic ointment (Epitezan $\AA^{\mathrm{c}}$ ) placed over the surgical wounds and into the conjunctival sac of each eye at intervals of 8 hours during 10 days and use of an Elizabethan collar.

\section{RESULTS AND DISCUSSION}

The low prevalence of feline entropion is in accordance with the literature. PRIESTER (1972) described just one case of entropion from a total of 22 diagnosed eye diseases. ZAJER \& SZUCS (1986) reported 10 cases of entropion from a total of 145 cats presenting different eye conditions.

Clinical evolution of both cases were observed at 1, 15, 30, 45 and 60 days following surgery. Both cats had satisfactory clinical evolution confirmed 15 days after surgery. The eyelid margins restored normal relationship to the globe and normal palpebral fissure with no sign of ocular irritation (figure 3 and figure 4).

There are information that suggest the predilection for Persian breed to present primary entropion (SLATTER, 1990b; NASISSE, 1991). Considering our casuistry, these two cases make this predilection evident.

STADES et al (1992) observed in breeds frequently affected, such as the Bouvier des Flandres, Labrador and Golden Retriever, and Persian cat, a longer mean of palpebral fissure lenght. This observation agreed with the great

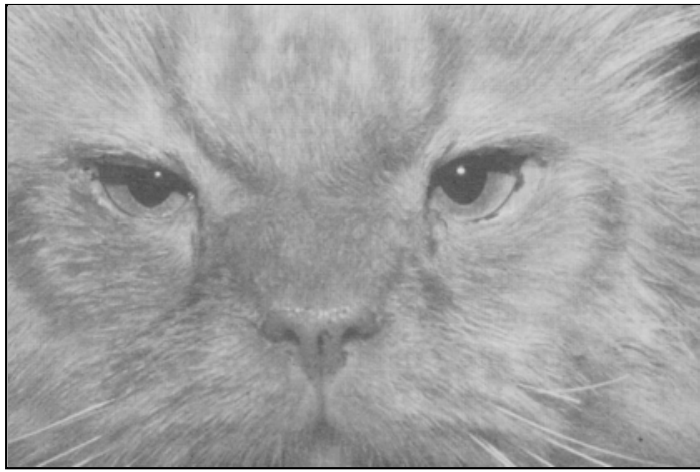

Figure 3 - First case: 30 days following surgery. The eyelid margins restored normal relationship to the globe and normal palpebral fissure with no sign of ocular irritation in the two years old male persian cat.

amount of inrolled eyelids showed at the ophthalmic examination of the cases here presented.

The modified Holtz-Celsus technique was easily performed and effective for correting feline entropion, which was verified 15 days after surgery.

Both cases may be considered primary feline entropion, although this type of structural defect rarely occurs in cats (NASISSE, 1991). The

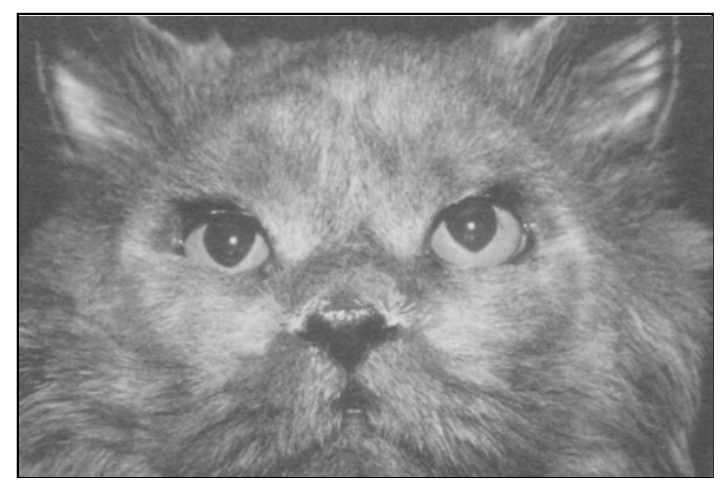

Figure 4 - Second case: 45 days following surgery. The eyelid margins restored normal relationship to the globe and normal palpebral fissure with no sign of ocular irritation in the one year old male persian cat.

chronic blepharospasm and ocular irritation was induced by the entropion, considering that both cats in this study had no history of trauma or overt abnormalities to account for the abnormal eyelids. In addiction, the entropion persisted after topical anaesthesia and relief of the blepharospastic component of entropion. The painful ocular disease increased spastic blepharospasm and ocular irritation. The resulting corneal ulceration in the second case accentuated severity of blepharospasm. 
The ulcer was superficial, with a nonadherent lip of epithelium around the ulcer's edge and exposed stroma. These findings are tipical of refractory corneal ulcer (WHITLEY, 1991).

In the second case, grid keratotomy was used for treatment of refractory ulcer. The loosened epithelium was removed with a cotton swab rubbed over the edge of the corneal lesion and affected area, and a hipodermic needle was used to make scratches over the ulcer site, exposing normal corneal stroma (WHITLEY, 1991). Keratotomy is the most effective procedure for treatment of refractory ulcer (MORGAN \& ABRAMS, 1994; STADSVOLD, 1995). According to SLATTER (1990a); GELATT (1991a) and HOPPER \& CRISPIN (1993), this corneal scrapings and swabs may be collected for culture early in the ophthalmic examination before treatment. Due to the absence of a severe purulent inflammation, corneal culture was not required and the ulcer was successfully treated with a broadspectrum bacteriostatic antibiotic.

Considering that these two cases suggested a breed-related feline entropion, the hypothesis of predisposition for primary feline entropion in Persian cats strengthen.

\section{SOURCES AND MANUFACTERS}

a - Halotano - Cristália Produtos Químicos e Farmacêuticos. b - 4-0 Vicryl - ETHICON.

c - Epitezan "Oculum" - Frumtost S.A.

\section{REFERENCES}

GELATT, K.N. Veterinary ophthalmology. 2 ed. Philadelphia: Lea \& Febiger, 1991a. Cap. 4:Ophthalmic examination and diagnostic procedures: p. 195-235.

GELATT, K.N. Veterinary ophthalmology. 2 ed. Philadelphia: Lea \& Febiger, 1991b. Cap. 6: The canine eyelids: p. 256-275.

HELPER, L.C. Magrane's canine ophthalmology. 4 ed.
Philadelphia: Lea \& Febiger, 1989. Cap. 4: Diseases and surgery of the lids and lacrimal apparatus: p. 51-89.

HOPPER, C.D., CRISPIN, S.M. Laboratory examination. In: PETERSON-JONES, S.M., CRISPIN, S.M. Manual of small animal ophthalmology. London: British Small Animal Veterinary Association, 1993, cap. 2, p. 37-43.

MORGAN, R.V., ABRAMS, K.L. A comparison of six different therapies for persistent corneal erosions in dogs and cats. Veterinary and Comparative Ophthalmology, v. 4, n. 1, p. 38-43, 1994.

NASISSE, M.P. Feline ophthalmology. In: GELATT, K.N. Veterinary ophthalmology. 2 ed. Philadelphia: Lea \& Febiger, 1991. Cap. 14, p. 329-575.

PETERSEN-JONES, S.M. Conditions of the eyelid and nictitanting membrane. In: PETERSEN-JONES, S.M., CRISPIN, S.M Manual of small animal ophthalmology. London: Britisth Small Animal Veterinay Association, 1993. Cap. 4, p. 65-89.

PRIESTER, W.A. Congenital ocular defects in cattle, horses, cats, and dogs. Journal of the American Veterinary Medical Association, v. 160, n. 11, p. 1504-1511, 1972.

SLATTER, D. Fundamentals of veterinary ophthalmology 2. ed. Philadelphia: Saunders, 1990a, cap. 5: Basic diagnostic techniques: p. 1-17.

SLATTER, D. Fundamentals of veterinary ophthalmology 2. ed. Philadelphia: Saunders, 1990b. Cap. 7: Eyelids: p. 147203.

STADES, F.C., BOEVE, M.H., WOERDT, A. van der. Palpebral fissure length in the dog and cat. Progress in Veterinary and Comparative Ophthalmology, v. 2, n. 4, p. 155-161, 1992.

STADSVOLD, N. A retrospective, comparative study of different treatments for corneal ulcers in dogs, cats and rabbits. DanskVeterinaertidsskrift, v. 78, n. 6, p. 271-276, 1995.

WHITLEY, R.D. Canine cornea. In: GELATT, K.N. Veterinary ophthalmology. 2 ed. Philadelphia: Lea \& Febiger, 1991. Cap. 9, p. 307-356.

ZAJER, J., SZUCS, Z. Eye diseases seen in dogs and cats at the Budapest veterinary school clinics in 1984. MagyarAllatorvosok-Lapja, v. 41, n. 2, p. 116-119, 1986.

Ciência Rural, v. 29, n. 4, 1999. 